\title{
GYVENTOJŲ INFORMUOTUMAS APIE ŠIRDIES IR KRAUJAGYSLIŲ LIGŲ PREVENCINĘ PROGRAMĄ
}

\author{
Sigutė Norkienė, Nida Pakalniškienė \\ Klaipédos universitetas
}

Raktažodžiai: širdies ir kraujagyslių ligos, širdies ir kraujagyslių ligų prevencinè programa.

\section{Santrauka}

Kraujotakos sistemos ligos yra viena iš pagrindiniu mirštamumo priežasčių kiekvienoje ES valstybejje narèje: jos sudare $50-60 \%$ visų mirčių Baltijos valstybėse ir Rumunijoje. Pastebima, jog gyventojai Lietuvoje, nepriklausomai nuo savo amžiaus, socialinès padèties bei išsilavinimo, nepakankamai rūpinasi savo sveikata. Tai gali priklausyti nuo daugelio priežasčių, kurių viena iš pagrindinių yra žinių trūkumas apie šias ligas. Iš anksto diagnozuojant ir gydant atitinkamus kraujotakos sistemos sutrikimus, vykdant reabilitacijos ir prevencines programas, apimančias sveikos gyvensenos mokymus, širdies ir kraujagysliu ligų plitimas gali būti ženkliai sumažintas. Lietuvoje pirminès asmens sveikatos priežiūros ịstaigos vykdo širdies ir kraujagyslių ligų tikimybès įvertinimo, pirminès prevencijos priemonių plano sudarymo, esant poreikiui siuntimo išsamiai ịvertinti širdies ir kraujagyslių ligų riziką paslaugas. Lietuvoje kasmet didèja gyventojų dalyvavimas prevencinėse programose, tačiau atliekant ịvairias apklausas ir tyrimus aiškèja, jog dauguma neturi pakankamai informacijos apie Lietuvoje vykdomas prevencines programas, todèl nepasiekiama maksimalaus gyventojų dalyvavimo tokiose programose. Metodika: anketinejje apklausoje dalyvavo 120 Klaipedos gyventojų, iš jų 60 vyrų ir 60 moterų. Statistinè duomenų analizè atlikta naudojant IBM SPSS 25. Rezultatai. Pagrindinį šios programos tikslą - sumažinti sergamumą širdies ir kraujagyslių ligomis žino didesnioji dalis respondentu, 65 proc.. Tačiau 23,6 proc. šio tikslo nežino. 7 iš 10 respondentų apie prevencinę programą informavo šeimos gydytojas arba slaugytojas. Visi apklaustieji respondentai sutinka, kad dalyvavimas širdies ir kraujagyslių ligų programoje gali sumažinti mirtingumą širdies ir kraujagyslių ligomis. Statistiškai reikšmingai tarp vyrų ir moterų skiriasi tik požiūris į sveiką gyvenseną, mankštinimosi ịpročiai, saldumynų vartojimas bei dalyvavimo prevencinèje programoje dažnumas, t.y. tiek vyrų, tiek moterų žinios apie prevencinę programą yra labai panašios. Skiriasi tik gyvenimo būdas. Nustatyta, kad moterys daug labiau domisi sveika gyvensena, nei vyrai. Pastebima, kad didžioji dalis gyventojų žino apie širdies ir kraujagyslių ligų ankstyvos diagnostikos programas ir teigia apie jų reikalingumą, tačiau dalyvavimas jose išlieka žemas. Didesnioji dalis respondentų norètu gauti daugiau informacijos apie ŠKL prevencinę programą.

\section{İvadas}

Sergamumas širdies ir kraujagyslių ligomis Lietuvoje išlieka vienas didžiausių Europoje ir nuo šių ligų miršta beveik du kartus daugiau gyventojų negu vidutiniškai ES šalyse. Situacija šiais klausimais prastesne tik Kipre ir Bulgarijoje (4). Vyrų mirtingumas nuo širdies ir kraujagyslių ligų beveik du kartus didesnis nei moterų. Nuo 2007 metų standartizuotas mirtingumo nuo širdies ir kraujagyslių ligų rodiklis Lietuvoje sumažèjo 65,3 mirusiojo 100 tūkst. gyventojų (4). Moterų mirtingumas sumažejo labiau negu vyrų. Standartizuotas mirtingumo nuo širdies ir kraujagyslių ligų rodiklis Lietuvoje beveik 2 kartus didesnis nei ES (4).

Lietuvoje mirtingumas nuo širdies ir kraujagyslių ligų ženkliai didesnis už Europos vidurkị, ligonių amžius jaunèja, o esančiomis profilaktikos programomis žmonès vis dar naudojasi vangiai. Statistiniai duomenys rodo, kad širdies ir kraujagyslių ligomis sergama paskutiniu metu rečiau, tačiau mirštama nuo jų net 3 kartus dažniau (7). Lietuvoje sudarytas darbingo amžiaus gyventojų širdies ir kraujagyslių ligų sergamumo bei mirtingumo žemèlapis atskleidè, jog Kaišiadorių rajone mirštančių nuo šių ligų skaičius yra didesnis nei Lietuvos vidurkis (7). Tuo tarpu sergamumas yra vienas iš didžiausių šalyje - taip pat kaip ir kaimyniniuose Širvintų, Jonavos ir Prienų rajonuose (7). Lietuvoje 2017 m. 
sudarytas žemėlapis patvirtino, kad 56 proc. gyventojų čia miršta nuo širdies ir kraujagyslių ligų (7). Pasak statistikos, 2015 metais Kaišiadorių rajono savivaldybeje iš 100 tūkst. gyventojų 109 moterys ir net 651 vyras mire būtent dèl širdies ir kraujagyslių ligų (7).

Pastebima, jog gyventojai Lietuvoje, nepriklausomai nuo savo amžiaus, socialinès padèties bei išsilavinimo, nepakankamai rūpinasi savo sveikata. Tai gali priklausyti nuo daugelio priežasčių, kurių viena pagrindinių yra žinių trūkumas apie šias ligas. Iš anksto diagnozuojant ir gydant atitinkamus kraujotakos sistemos sutrikimus, vykdant reabilitacijos ir prevencines programas, apimančias sveikos gyvensenos mokymus, širdies ir kraujagyslių ligų plitimas gali būti ženkliai sumažintas.

Dauguma išsivysčiusių šalių ir kai kuriose Europos šalyse, pvz., Lenkijoje, Čekijoje, matoma mirtingumo nuo pagrindinių širdies ir kraujagyslių ligų mažejimo tendencija (4). Mirtingumas mažejja minètose šalyse dèl to, kad visuomenejje ženkliai sumažejo svarbiausių širdies ir kraujagyslių ligų rizikos veiksnių, ypač rūkymo, aukšto cholesterolio kiekio kraujyje ir arterinès hipertenzijos atvejų, taip pat ịtakos turejjo ir šiuolaikiniai širdies ir kraujagyslių ligų gydymo metodai (4). Šie pokyčiai gali būti dèl naujų chirurginių procedūrų taikymo, naujų vaistų vartojimo, taip pat pacientų gyvenimo būdo pokyčių (pvz. rūkančiųjų skaičiaus mažejjimo). Taip pat bent iš dalies ir dél vykdomų širdies ir kraujagyslių ligų prevencinių programų.

Visuomeneje vyrauja klaidinga nuomonè, kad kraujotakos sistemos ligos tai tik vyresnio amžiaus žmonių problema. Todèl dauguma jaunų žmonių nesirūpina šių ligų profilaktika. Tikètina, kad žmonės, priskirtini širdies ir kraujagyslių ligų didelès rizikos grupei, nesikreipia pas specialistą tol, kol nepajaučia rimto sveikatos sutrikimo, gyvenimo kokybės pablogèjimo. Labai svarbu suprasti, jog kraujotakos sistemos ligas sąlygoja visą gyvenimą žmogų veikiantys ịvairūs sveikatą lemiantys veiksniai. Būtina nuolatos, nuo gimimo iki pat mirties, rūpintis savo sveikata, laikytis sveikos gyvensenos principų bei imtis visų galimų profilaktikos priemonių, kad būtų išvengta neigiamų pasekmių. Be to, šios ligos ankstyvojoje stadijoje dažniausiai vystosi be lengvai pastebimų simptomų, todèl žmogų užklumpa netikètai, dažniausiai kai liga jau yra pažengusi (9).

2005 m. lapkričio 25 d. Lietuvos Respublikos sveikatos apsaugos ministras išleido įsakymą ,Dèl asmenų, priskirtinų širdies ir kraujagyslių ligų didelès rizikos grupei, atrankos ir prevencijos priemonių finansavimo programos patvirtinimo" (10). Iki šios dienos buvo išleisti 9 ši pirminį ịsakymą keičiantys ar papildantys įsakymai. Širdies ir kraujagyslių ligų (toliau ŚKL) prevencinès programos (toliau PP) tikslas - sumažinti sergamumą ūminiais kar- diovaskuliniais sindromais, nustatyti naujus latentinių aterosklerozès būklių ir cukrinio diabeto atvejus, siekiant sumažinti pacientų neiggalumą ir mirtingumą dèl ŠKL.

Tyrimo tikslas - išanalizuoti gyventojų informuotumą apie širdies ir kraujagyslių ligų prevencinę programą.

\section{Tyrimo metodika}

Lietuvos statistikos departamento duomenimis, $2017 \mathrm{~m}$. Klaipėdos savivaldybejje gyveno 151309 gyventojai, iš jų 39 887 moterys 50 - 65 metų amžiaus bei 34818 vyrų $(40-55$ metų amžiaus vyrai). Išskiriamos tik šios dvi amžiaus grupès, nes širdies ir kraujagyslių ligų prevencinès programos paslauga teikiama vyrams nuo 40 iki 55 metų, moterims nuo 50 iki 65 metų. Iš viso tyrime dalyvavo120 gyventojų: iš jų 60 vyrų ir 60 moterų.

Tyrime dalyvauti buvo kviečiami atsitiktiniai $40-55$ metų vyrai ir 50 - 65 metų moterys, kurie tuo metu, dèl ịvairių priežasčių lankèsi poliklinikoje. Tyrime taikyta apklausa raštu naudojant anketą, sudarytą iš klausimų, leidžiančių spręsti apie gyventojų informuotumą apie ŠKL PP.

Vertinant respondentų sociodemografines charakteristikas nustatyta, kad didesnioji dalis apklaustujų 62-65 m. amžiaus grupejje (24,5 proc.), toliau seka 56-61 m. amžiaus grupè (21,9 proc.). 40-45 m. amžiaus grupèje apklausta 18,3 proc. respondentų ir 15,9 proc. apklaustujjų $46-50 \mathrm{~m}$. amžiaus grupèje. 51-55 m. amžiaus grupèje apklausta 19,4 proc. respondentų. Galima teigti, kad apklausiami respondentai pagal amžiaus grupes pasiskirste tolygiai. Vidutiniškai apklausti visų grupių asmenys. Didžiausią dalị apklaustujjų sudaro asmenys su profesiniu/aukštesniuoju išsilavinimu.

Kadangi viena iš tyrimo užduočių yra palyginti vyrų ir moterų žinias apie Lietuvoje vykdomą širdies ir kraujagyslių ligų prevencijos programą, buvo apklaustas vienodas 40 55 metų vyrų ir $50-65$ metų moterų skaičius. Statistinè duomenų analizė atlikta naudojant IBM SPSS 25 (Statistical Package for Social Sciences). Vyrų bei moterų žinių palyginimui taikytas Chi kvadratu kriterijus ir dažnių lentelès. Rezultatai pateikiami lentelèse ir diagramose, kurios braižytos naudojant Microsoft Office Word 2016 ir Microsoft Office Exel 2016 programas.

\section{Rezultatai}

Tyrimo metu identifikuota, kad net 67,3 proc. respondentų turi žalingų ịpročių ir tik 32,7 proc. mano kad jų neturi. Didesnioji jų dalis visiškai nesimankština (48,3 proc.). 2-3 kartus per savaitę mankštinasi tik 34 proc. apklaustujų respondentų, o mankštinasi 4 ir daugiau kartų per savaitę tik 10,3 proc. apklaustujų. Apklausos rezultatai patvirtina, kad aktyvia fizine veikla neužsiimantys daugiau nei 2-3 kartus per savaitę gyventojai labiau rizikuoja susirgti hipertenzija, 
insultu ir kitomis širdies ligomis.

Analizuojant mitybos ịpročius, pastebètina, kad tik 23,7 proc. atsake, jog valgo bet ką ir bet kada, tuo tarpu košèmis dieną pradeda daugiau kaip pusè tiriamujų, greito ir nesveiko maisto vengia beveik 45 proc. Daugiau ar mažiau sveika gyvensena domisi daugiau nei 80 proc. apklaustujų. Respondentų atsakymų pasiskirstymas apie mitybos ịpročius pateikiamas 1 paveiksle.

Respondentų atsakymų pasiskirstymas apie domėjimąsi sveika gyvensena pateikiamas 2 paveiksle.

Didesnioji dalis respondentų domisi sveika gyvensena tik tiek, kiek, jų nuomone, jiems reikia. Taip teigia 45,7 proc. apklaustujų. Sveika gyvensena domisi tik 23,6 proc. gyventojų. Manytina, kad tai nedidelis kiekis. Kadangi tyrimo tikslas - nustatyti asmenų informuotumą apie ŠKL PP, respondentų klausta - ar jie žino apie šiuo metu Lietuvoje vykdomą nemokamą širdies ir kraujagyslių ligų prevencijos programą. Nustatyta, kad apie Lietuvoje vykdomą nemokamą širdies ir kraujagyslių ligų prevencijos programą žino apie

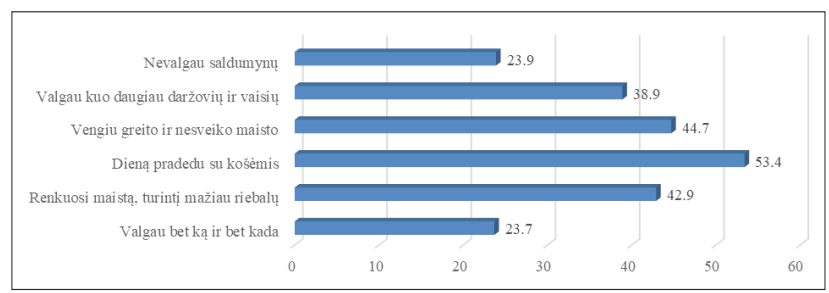

1 pav. Apklaustų respondentų mitybos ịpročiai.

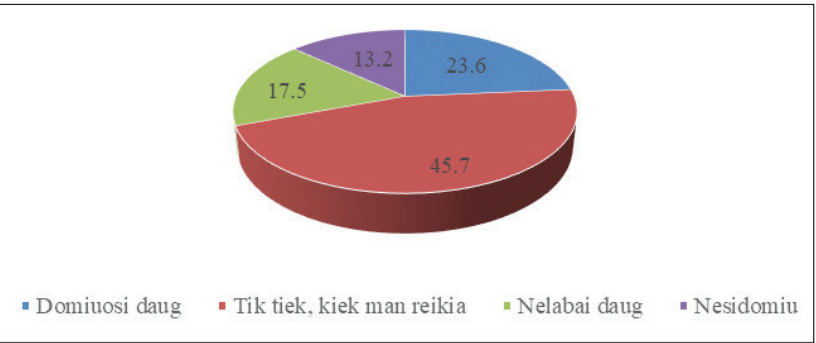

2 pav. Apklaustų respondentų domëjimasis sveika gyvensena.

1 lentelè. Klaipèdos gyventojų žinios apie šiuo metu Lietuvoje vykdomą nemokamą ŠKL PP.

\begin{tabular}{|l|c|c|}
\hline & $\begin{array}{l}\text { Jūs žinote apie šiuo } \\
\text { metu Lietuvoje vyk- } \\
\text { domą nemokamą ŠKL } \\
\text { PP? }\end{array}$ & $\begin{array}{l}\text { Turiu pakankamai } \\
\text { žinių kur kreiptis, } \\
\text { norint sudalyvauti } \\
\text { ŠKL PP }\end{array}$ \\
\hline Visiškai nežinau & 1.3 & 4.3 \\
\hline Nežinau & 11.7 & 10.4 \\
\hline Abejoju & 10.4 & 13.7 \\
\hline Žinau & 52.8 & 37.4 \\
\hline Gerai žinau & 23.8 & 34.2 \\
\hline
\end{tabular}

80 proc. apklaustujų, tai yra beveik toks pat procentas, kaip ir $2016 \mathrm{~m}$. Lietuvoje atlikto tyrimo atveju. Informacija susistemintai pateikta 1 lentelèje.

Taip pat domètasi, ar gyventojai turi pakankamai žinių, kur kreiptis, norint sudalyvauti širdies ir kraujagyslių ligu prevencineje programoje. Šie rezultatai atskleidè, kad faktiškai 70 proc. apklaustujų turi pakankamai žinių, kur kreiptis, norint sudalyvauti širdies ir kraujagyslių ligų prevencinèje programoje (1 lentelè). Galima konstatuoti, kad šios programos sklaida yra pakankamai vykdoma.

Tyrimo metu domėtasi, ar gyventojai žino, kokių amžiaus grupių asmenims skirta nemokama širdies ir kraujagyslių ligų prevencijos programa. Tik du trečdaliai respondentų tiksliai žino amžiaus grupes, kurioms skirta nemokama širdies ir kraujagyslių ligų prevencijos programa. Informacija pateikta 3 paveiksle ir matome, kad net 65 proc. apklaustujų žino tikslią šios prevencinès programos naudotojų grupę - vyrams

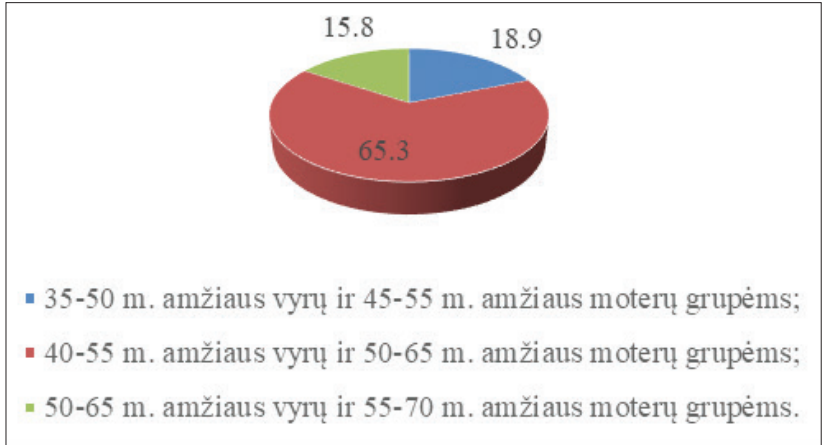

3 pav. Gyventojų informuotumas apie tai, kokių amžiaus grupių asmenims skirta nemokama ŠKL PP.

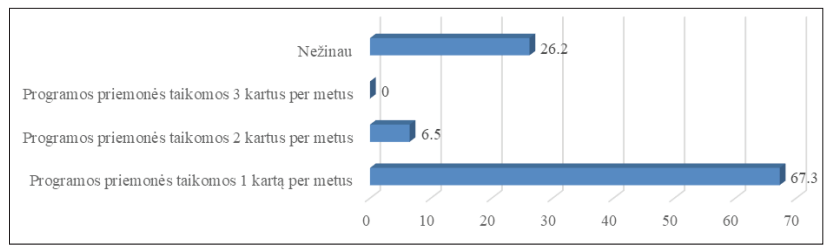

4 pav. Klaipėdos gyventojų informuotumas apie tai, kiek kartu per metus galima pasinaudoti vykdomos nemokamos ŠKL PP priemonemis.

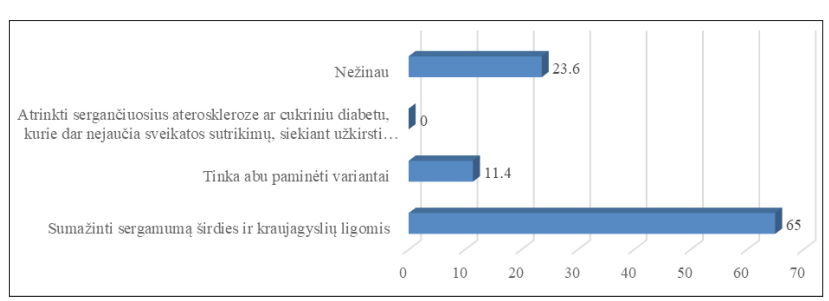

5 pav. Klaipėdos gyventojų informuotumas apie tai, koks yra vykdomos nemokamos ŠKL PP tikslas. 
nuo 40 iki 55 metų, moterims nuo 50 iki 65 metų.

Taip pat buvo siekiama nustatyti, ar gyventojai žino, kiek kartų per metus galima pasinaudoti vykdomos nemokamos širdies ir kraujagyslių ligų prevencijos programos priemonemis.

Nustatyta, kad taip pat tik du trečdaliai žino, kad šia programa galima pasinaudoti tik kartą per metus. Domètasi, ar respondentai žino, koks yra vykdomos nemokamos širdies ir kraujagyslių ligų prevencijos programos tikslas. Informacija susisteminta 5 paveiksle.

Rezultatai parodè, kad pagrindinį šios programos tikslą - sumažinti sergamumą širdies ir kraujagyslių ligomis žino didesnioji dalis respondentų, 65 proc. (6 pav.). Tačiau 23,6 proc. šio tikslo nežino.

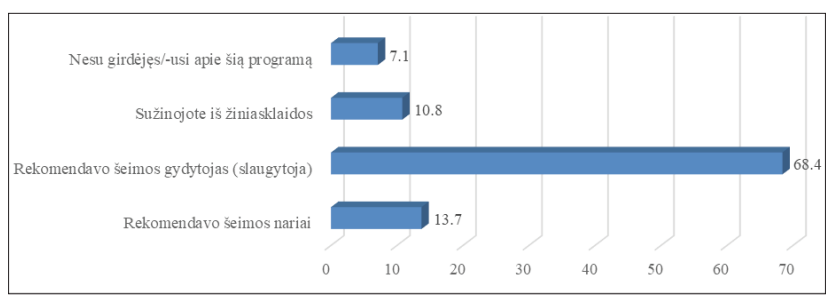

6 pav. Klaipėdos gyventojų nuomonė apie šaltinius, suteikiančius informaciją apie SKL PP.

2 lentelė. Klaipėdos gyventojų nuomonė apie ŠKL PP naudingumą ir informuotumą.

\begin{tabular}{|l|c|}
\hline Teiginiai & $\begin{array}{c}\text { Vidutiniai } \\
\text { vertinimai }\end{array}$ \\
\hline $\begin{array}{l}\text { Dalyvavimas šioje programoje gali sumažinti mir- } \\
\text { tingumą širdies ir kraujagyslių ligomis }\end{array}$ & 4,8 \\
\hline Turiu pakankamai žinių apie šią programą & 3,5 \\
\hline $\begin{array}{l}\text { Gydymo įstaigos darbuotojai pakankamai paaiškino, } \\
\text { kodėl reikètų dalyvauti šioje programoje }\end{array}$ & 3,7 \\
\hline $\begin{array}{l}\text { Savo poliklinikoje gaunu pakankamai informacijos } \\
\text { apie ŠKL PP }\end{array}$ & 4,1 \\
\hline $\begin{array}{l}\text { Pageidaučiau, kad gydymo ịstaigos darbuotojai su- } \\
\text { teiktų daugiau informacijos apie ŠKL PP }\end{array}$ & 3,8 \\
\hline Aš labai domiuosi sveika gyvensena & 2,7 \\
\hline
\end{tabular}

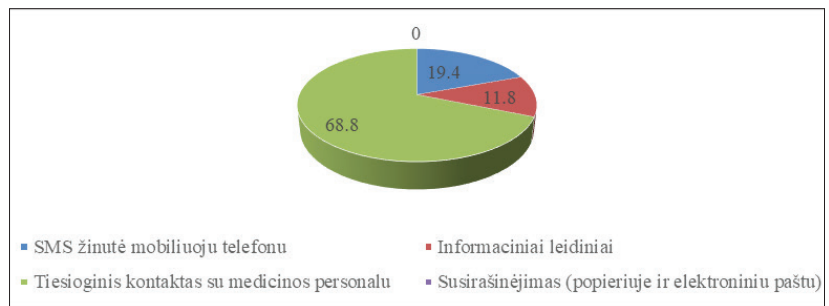

7 pav. Klaipėdos gyventojų nuomonè apie veiksmingiausias bendradarbiavimo formas, skatinančias dalyvavimą prevencinès veiklos srityje.
Teirautasi, iš kokių šaltinių Klaipedos gyventojai sužinojo apie ŠKL prevencinę programą. 7 iš 10 respondentų apie prevencinę programą informavo šeimos gydytojas arba slaugytojas. Procentinis pasiskirstymas pateiktas 6 paveiksle. Šie skaičiai labai panašūs ị 2016 m. Lietuvoje atlikto tyrimo rezultatus.

Paaiškejo, kad pagrindinis informacijos šaltinis - tai šeimos gydytojo arba slaugytojos suteikta informacija. Tai

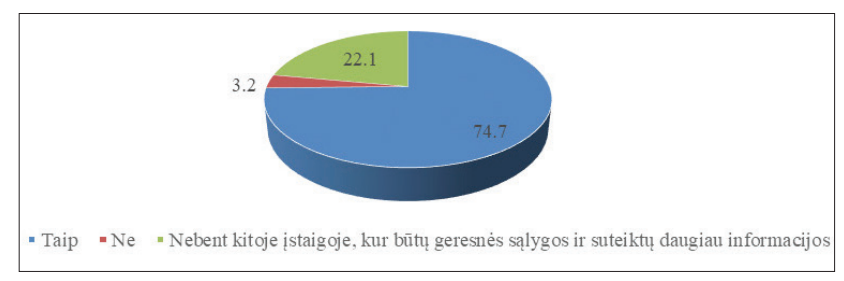

8 pav. Klaipėdos gyventojų nuomonė apie rekomendavimą savo artimiesiems ar pažistamiems sudalyvauti ŠKL prevencineje programoje.

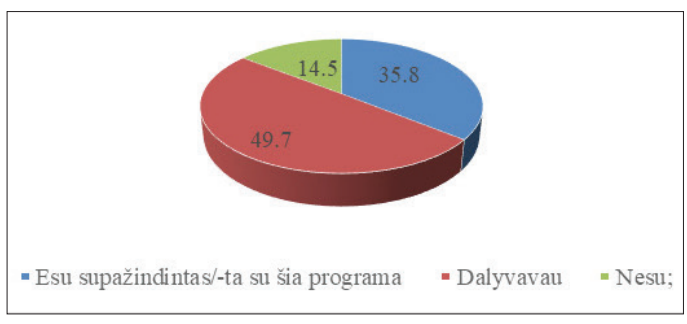

9 pav. Klaipėdos gyventojų dalyvavimo ŠKL prevencinèje programoje proc. pasiskirstymas.

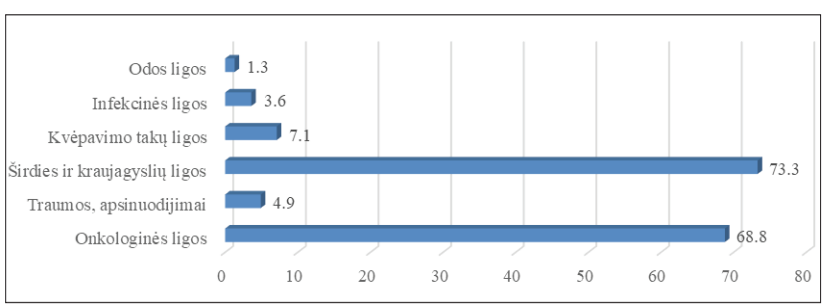

10 pav. Klaipėdos gyventojų nuomone, kokios ligos dažniausiai yra mirties priežastis Lietuvoje.

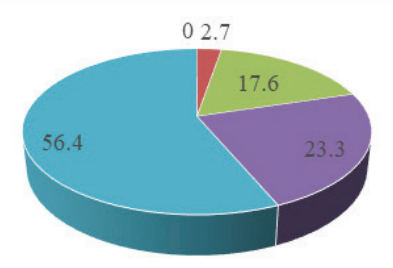

- Visiškai nesutinku - Nesutinku = Abejoju - Sutinku = Visiškai sutinku

11 pav. Klaipėdos gyventojų nuomonès klausimu, ar jie turi širdies ir/arba kraujagyslių sistemos sutrikimų, pasiskirstymas proc. 
nurodè 68,4 proc. respondentų. Vis dèlto 7 proc. respondentu nèra girdèję apie ŠKL PP. Tam tikrai daliai respondentų rekomendavo šeimos nariai (13,7 proc.).

Tyrimo metu nustatyta, kad beveik visi apklaustieji respondentai sutinka, kad dalyvavimas ŠKL programoje gali sumažinti mirtingumą širdies ir kraujagyslių ligomis (2 lentelè).

Taip pat gyventojai mano, kad gydymo įstaigos darbuotojai pakankamai paaiškina, kodèl reikètų dalyvauti šioje programoje, tačiau, iš kitos pusès, jie pageidautų, kad gydymo istaigos darbuotojai suteiktų daugiau informacijos apie širdies ir kraujagyslių ligų prevencijos programą. Tai vieni kitiems prieštaraujantys atsakymai.

Respondentai mano, kad pati veiksmingiausia bendradarbiavimo forma, skatinanti dalyvavimą ŠKL prevencinès veiklos srityje, yra - tiesioginis kontaktas su medicinos personalu. Taip teigia net 68,8 proc. apklaustujų ( 7 pav.), Mobiliomis technologijomis pasitiki 19,4 proc. respondentų. Susirašinèti popieriniais laiškais ar elektroniniu paštu nenorètų nei vienas respondentas.

Pasiteiravus respondentų, ar rekomenduotų savo artimiesiems ar pažįstamiems sudalyvauti širdies ir kraujagyslių ligu prevencineje programoje, nustatyta, kad didesnioji dalis $(74,7$ proc,) tai padarytų. Apie 22 proc. respondentų siūlytų tai atlikti kitoje įstaigoje, kur būtų geresnès sąlygos ir suteiktų daugiau informacijos (8 pav.).

Nors turi nemažai žinių, tačiau programoje dalyvavo tik pusė apklaustujų (49,7 proc.) (9 pav.), o beveik 36 proc. yra supažindinti su šia programa.

Nedalyvavimo priežastys: laiko trūkumas (29,3 proc.), informacijos trūkumą îvardijo 19 proc. apklaustujų, nepasitikèjimą medicininiu personalu įvardijo 14.6 proc. Net 36,8 proc. respondentų nežino priežasčių, kodèl nedalyvauja ŠKL PP. Identifikuota, kad didesnioji dalis respondentų dalyvauja ŠKL PP kiekvienais metais.

Tiriamieji žino, kad pagrindinès mirties priežastys Lietuvoje yra širdies ir kraujagyslių ligos bei onkologinès ligos.

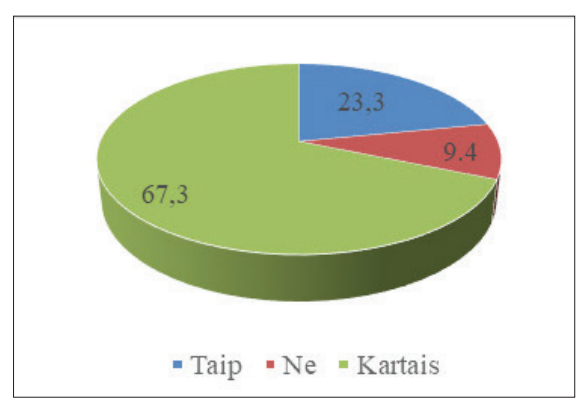

12 pav. Klaipėdos gyventojų nuomonès proc. pasisakymas apie vartojamus širdies veiklą gerinančius vaistus, maisto papildus.
Respondentų nuomonè, dẻl kokių ligų dažniausiai miršta Lietuvoje gyventojai pateikta 10 paveiksle.

Tyrimas parodè, kad širdies ir kraujagyslių ligos gyventojų požiūriu yra viena iš pagrindinių ligų, sukeliančių mirtị.

Respondentų buvo klausiama - ar jie turi širdies ir/arba kraujagyslių sistemos sutrikimų. Beveik 57 proc. apklaustujų visiškai sutiko, kad šių sutrikimų turi (11 pav.) 23 proc. Tai patvirtino tik sutikimu. 17,6 proc. respondentu abejoja šiuo klausimu.

Tyrimo metu domètasi, ar gyventojai vartoja širdies veiklą gerinančius vaistus, maisto papildus. Nustatyta, kad beveik 68 proc. respondentu tai daro tik kartais, o nuolat vartoja tik apie 23 proc. apklaustujjų (12 pav.). Tai leidžia manyti, kad gyventojai atmestinai žiūri ị papildų, gerinančių jų širdies darbą vartojimą.

Gyventojų informuotumas, dalyvavimas ir požiūris i prevencines programas susijęs su demografiniais ir socialiniais veiksniais - lytimi ir išsilavinimu, todèl aktualu tyrimą tęsti nustatant skirtumus tarp šių veiksnių. Vyrų bei moterų žinių palyginimui taikytas Chi kvadratu kriterijus ir dažnių lentelès. Chi kvadrtu kriterijus dar vadinamas požymių nepriklausomumo kriterijumi tiria, ar nagrinejjami požymiai

3 lentelè. Vyrų bei moterų žinių palyginimas taikant Chi kvadratu kriterijus.

\begin{tabular}{|l|c|c|}
\hline & $\begin{array}{c}\text { Chi } \\
\text { kva- } \\
\text { dratu }\end{array}$ & $\begin{array}{c}\text { p } \\
\text { reikšmė }\end{array}$ \\
\hline Sveika gyvensena & $\mathbf{9 . 7 7 1}$ & $\mathbf{0 . 0 2 1}$ \\
\hline Žalingi ịpročiai & 1.096 & 0.295 \\
\hline Mankštinimosi ịpročiai & $\mathbf{1 0 . 5 3}$ & $\mathbf{0 . 0 1 5}$ \\
\hline $\begin{array}{l}\text { Jūs turite širdies ir/arba kraujagyslių siste- } \\
\text { mos sutrikimų }\end{array}$ & 3.08 & 0.379 \\
\hline Valgau bet ką ir bet kada & 0.692 & 0.406 \\
\hline Renkuosi maistą, turintį mažiau riebalų & 0.022 & 0.882 \\
\hline Dieną pradedu su košèmis & 0.102 & 0.749 \\
\hline Vengiu greito ir nesveiko maisto & 0.905 & 0.341 \\
\hline Valgau kuo daugiau daržovių ir vaisių & 0.214 & 0.644 \\
\hline Nevalgau saldumynų & $\mathbf{4 . 7 8 1}$ & $\mathbf{0 . 0 2 9}$ \\
\hline $\begin{array}{l}\text { Jūs žinote apie šiuo metu Lietuvoje vyk- } \\
\text { domą nemokamą ŠKL PP }\end{array}$ & 4.295 & 0.368 \\
\hline $\begin{array}{l}\text { Turiu pakankamai žinių kur kreiptis, norint } \\
\text { sudalyvauti ŠKL PP }\end{array}$ & 2.122 & 0.713 \\
\hline $\begin{array}{l}\text { Ar dalyvavote (-aujate) šioje prevenci- } \\
\text { nėje programoje }\end{array}$ & $\mathbf{7 . 4 4 9}$ & $\mathbf{0 . 0 2 4}$ \\
\hline $\begin{array}{l}\text { Dėl kokių priežasčių nedalyvaujate pro- } \\
\text { gramoje }\end{array}$ & 0.859 & 0.835 \\
\hline $\begin{array}{l}\text { Kiek kartų esate dalyvavęs/-usi šioje pro- } \\
\text { gramoje }\end{array}$ & 2.997 & 0.223 \\
\hline $\begin{array}{l}\text { Ar Jūs žinote, kur turètumėte kreiptis, no- } \\
\text { rint sudalyvauti ŠKL PP }\end{array}$ & 0.831 & 0.362 \\
\hline
\end{tabular}


yra susiję, šiuo atveju ar žinios bei požiūris i prevencinę programą priklauso nuo lyties. Požymiai yra priklausomi, jeigu Chi kvadratu testo p reikšmė yra mažesnè už 0.05 .

3 lenteleje pateikti testo rezultatai rodo, kad statistiškai reikšmingai tarp vyrų ir moterų skiriasi tik požiūris ị sveiką gyvenseną, mankštinimosi ịpročiai, saldumynų vartojimas bei dalyvavimo prevencinejje programoje dažnumas, t. y. apibendrinant galima teigti, kad tiek vyrų, tiek moterų žinios apie prevencinę programą yra labai panašios. Skiriasi tik gyvenimo būdas.

Tyrimo metu nustatyta, nors vyrai turi šiek tiek daugiau žalingų ịpročių, šis skirtumas nèra statistiškai reikšmingas. Kaip jau minèta - mankštinimosi ịpročiai skiriasi statistiškai reikšmingai. Matome, kad vyrai yra linkę mankštintis daugiau, nei moterys.

Tyrimo metu nustatyta, kad saldumynais labiau linkę piktnaudžiauti vyrai. Nors statistiškai reikšmingų skirtumų nèra, tačiau matome, kad šiek tiek daugiau moterų sutinka, kad turi širdies ir/arba kraujagyslių ligų sistemos sutrikimų. Taip pat šiek tiek daugiau moterų žino apie šiuo metu Lietuvoje vykdomą prevencijos programą. Daugiau žinių apie tai, kur kreiptis, norint sudalyvauti širdies ir kraujagyslių ligų prevencineje programoje, taip pat teigia turinčios moterys, nors šis skirtumas ir nèra statistiškai reikšmingas. Taip pat nustatyta, kad didesne dalis moterų nei vyrų dalyvavo prevencineje programoje. Kad nepasitiki medicininiu personalu ir dèl to nedalyvauja ŠKL PP daugiau teigè vyrai nei moterys, kitų nedalyvavimo priežasčių dèstymas faktiškai nesiskiria tarp vyrų ir moterų. Nustatyta, kad moterys žymiai labiau informuotos, kur turètų kreiptis, noredamos sudalyvauti širdies ir kraujagyslių ligų prevencinèje programoje.

\section{Rezultatų aptarimas}

Nagrinejjant ŠKL PP teisinius aspektus pastebèta, kad siekiant efektyvumo iki 2018 metu buvo priimta 11 šios i̊statyminès bazès pakeitimų. Kasmet augančios ŠKL PP igyvendinimui skiriamos lèšos ir dalyvaujančiu žmonių skaičius rodo vis didesnị visuomenès informuotumą. Dar 2012 metais apie ŠKL PP žinojo tik 34 proc. apklaustujų $(n=1020)$, tačiau apklausiant 2017 metais, respondentų informuotumas buvo kur kas aukštesnis (66 proc.) ir visų prevencinių programų labai panašus. Tačiau nepaisant vis augančio Lietuvos gyventojų informuotumo, prevencinių programų efektyvumas lieka ne iki galo išaiškintas.

Kadangi PP apmokamos iš PSDF biudžeto lèšų ir teikiamos PAASPI , pirminès sveikatos priežiūros specialistams, bendrosios praktikos slaugytojams bei gydytojams, kurie yra tiesioginè grandis tarp visuomenès ir sveikatos priežiūros sistemos, tenka didžiausias informacijos sklaidos apie vykdomas PP vaidmuo. Lietuvos autorių tyrimai patvirtina, jog jie atlieka svarbų vaidmenį informuodami ir skatindami gyventojus dalyvauti. Manoma, kad glaudžiai bendradarbiaujant visuomenès sveikatos tarnyboms ir pirminès sveikatos priežiūros grupèms, galima sumažinti didèjantį ŠKL plitimą (11).

Dalyvaudami ŠKL PP vyresni nei 40 metų vyrai bei vyresnès nei 50 metų moterys kartą per metus gali nemokamai atlikti visus reikalingus tyrimus. Jie atskleidžia organizmo būklę ir parodo, kokio gydymo reikia. Lietuvos gyventojams svarbu žinoti, kad vieną kartą per metus nemokamai gali būti nustatoma gliukozès, cholesterolio, trigliceridų koncentracija kraujyje, atliekama elektrokardiograma ir kiti tyrimai, parodantys, ar žmogus priskirtinas didelès rizikos grupei. Apskaičiuota, kad Lietuvoje gyvena apie 675 tūkstančiai tokio amžiaus žmonių. Gyventojų patikros šalies mastu tikslas - mažinti sergamumą ŠKL (krūtinès angina, miokardo infarktu, smegenų išemija, insultu, periferinių arterijų tromboze), identifikuoti sergančiuosius ateroskleroze ar cukriniu diabetu, kurie dar nejaučia sveikatos sutrikimų, siekiant užkirsti kelią šių ligų raidai. Taikomų prevencinių priemonių efektyvumas pagristas medicinos mokslu ir kitų šalių patirtimi.

Norvegijos mokslininkai teigia, kad pacientų ugdymas reikalauja gerai informuotų sveikatos priežiūros specialistų, turinčių pažangių bendravimo ịgūdžių ir pedagoginių gebèjimų, leidžiančių jiems motyvuoti pacientus ir teikti veiksmingą, ị pacientą orientuotą gyvenimo būdo informaciją (13). Ispanijos mokslininkai nustate, kad sėkmingas ŠKL PP igyvendinimas itin susijęs su pirminès sveikatos priežiūros gydytojų, atliekančių gyventojų ugdymą ir pateikiančių informaciją apie ŠKL rizikos veiksnius (3).

VLK specialistams apdorojus duomenis apie prevencinių programų vykdymą paaiškèjo, kad 2017 metais ŠKL PP dalyvavo daugiau kaip 266 tūkstančiai žmonių, iš jų daugiau nei 17-kai tūkstančių gydytojai paskyrè papildomus tyrimus ir gydymą (1). Darytina išvada, kad kuo aktyviau gyventojai tikrinasi, dalyvauja ŠKL prevencijos programoje, tuo daugiau duomenų surenkama (7). Taip galima anksčiau diagnozuoti ŠKL problemas ir tuo pačiu kontroliuoti ligas, o paskyrus tinkamą gydymą, išvengti skaudžių pasekmių. Valstybès kompensuojama ŠKL PP leidžia kartą per metus išsitirti širdies ir kraujagyslių sistemos būklę. Jei šeimos gydytojas nustato, kad ŠKL tikimybe yra didelè, jis siunčia pacientą i specializuotus centrus išsamiau ištirti širdị ir kraujagysles, o prireikus - skiriamas gydymas. Jei nustatoma, kad gyventojas priklauso rizikos grupei, jam sudaromas individualus profilaktikos planas, atsižvelgiant ị paciento sveikatos būklę skiriamos veiksmingos profilaktinès priemonès: sveika mityba, rekomendacijos dèl fizinio aktyvumo, aptariamas rūkymo stabdymas, reikalui esant priešhipertenziniai vaistai ir aterosklerozę stabdantys statinai. Bendrosios praktikos 
slaugytojams bei gydytojams tenka didžiausias informacijos sklaidos apie vykdomas ŠKL PP vaidmuo.

2016 metu apklausos rezultatai parodé, kad daugiau nei aštuoni iš dešimties ( 85 proc.) suaugusių Lietuvos gyventojų yra informuoti apie nemokamas prevencines programas, t.y. žino, kad tam tikro amžiaus asmenys gali nemokamai dalyvauti prevencinėse programose, kurių paslaugas apmoka ligonių kasos (1). 6 iš 10 apklaustu gyventojų Lietuvoje žino apie širdies ir kraujagyslių ligų prevencines programas. Nežinančių nè vienos prevencinès programos šiuo metu yra septintadalis respondentų (per paskutinius metus informuotų gyventojų dalis padidejo 3 procentiniais punktais, o per paskutinius 3 metus žinančių bent vieną prevencinę programą padidejo 18 procentinių punktų). Trys iš dešimties gyventojų 2016 metais norejo daugiau sužinoti apie širdies ir kraujagyslių ligų prevencinę programą. $2016 \mathrm{~m}$. buvo nustatytas stabilus ir teigiamas požiūris ị ligonių kasų apmokamas prevencines programas - 9 iš 10 suaugusių Lietuvos gyventojų sutinka su teiginiu, kad nemokamos prevencinès programos yra reikalingos bei 8 iš 10 apklaustų gyventojų nurodè, kad, jei jiems būtų pasiūlyta dalyvauti nemokamose prevencinèse programose (pvz., skirtose širdies ir kraujagyslių ligų prevencijai ar ankstyvam véžio diagnozavimui), jie sutiktų dalyvauti. Svarbiausi motyvai, kodèl nenori dalyvauti prevencinèse programose - kaip ir anksčiau gyventojai, kurie nesutiktų dalyvauti tokiose programose, dažniausiai nurodé, kad tai jiems neaktualu, kol kas jie nenori apie tai galvoti (kas antras neketinančių dalyvauti). Kiti dažniau nurodomi atsisakymo motyvai - bijo sužinoti galimus blogus tyrimu rezultatus, pasiteisinimas dèl laiko stokos bei baimè, kad poliklinikose būna didelès tyrimų eilès.

Apibendrinus tyrimo rezultatus pastebèta, kad aštuoni iš dešimties (81 proc.) suaugusių Lietuvos gyventojų yra informuoti apie nemokamas prevencines programas, t.y. žino, kad nustatyto amžiaus asmenys gali nemokamai dalyvauti prevencinėse programose, kurių paslaugas apmoka ligonių kasos - du trečdaliai apklaustų gyventojų Lietuvoje (18 metų ir vyresnių) žino apie širdies ir kraujagyslių ligų (66 proc.) prevencinę programą (1). Trys iš dešimties gyventojų nori daugiau sužinoti apie širdies ir kraujagyslių ligu prevencinę programą. Apklausa parodè, kad po septintadali dalyvavo širdies ir kraujagyslių ligų (13 proc. vyrų ir 16 proc. moterų, tarp tikslinès grupès respondentu -23 proc.) prevencinejje programoje. Stabilus ir teigiamas požiūris i ligonių kasų apmokamas prevencines programas - kaip ir prieš metus, 8 iš 10 apklaustų gyventojų nurodè, kad, jei jiems būtų pasiūlyta dalyvauti nemokamose prevencinèse programose (pvz., skirtose širdies ir kraujagyslių ligų prevencijai), jie sutiktų dalyvauti. Svarbiausias vaidmuo tenka šeimos gydytojui - trys ketvirtadaliai (75 proc.) apklaustų suaugusių Lietuvos gyventojų norètų, kad apie nemokamas prevencines programas juos informuotų bei pakviestų dalyvauti šeimos gydytojai (tai nurodžiusių dalis per paskutinius 4 metus išlieka stabili).

Pagal Europos Sajungos rekomendacijas, siekiant PP efektyviai mažinti gyventojų mirtingumą, rekomenduojama ne mažesnè nei 80 proc. dalyvių aprèptis programose (5). $2008 \mathrm{~m}$. tyrimų duomenimis, dalyvių PP apimtys priklauso ir nuo gydytojų elgsenos, t. y. apsisprendimo teikti ar ne PP paslaugas, taip pat nuo jų gebejjimo užtikrinti teikiamų paslaugų kokybę (12).

Užsienio tyrimų rezultatai leidžia teigti, kad gydytojai atlieka svarbų vaidmeni informuodami ir motyvuodami gyventojus dalyvauti programose $(6,8)$. Nustatyta, kad pirminès sveikatos priežiūros grandyje dirbantis gydytojas yra vienas pagrindinių ar net pagrindinis gyventojų informuotumo apie PP programas šaltinis (2). Gyventojai savo požiūrị apie sveikatos apsaugos sistemą susidaro būtent bendraudami su pirminès sveikatos priežiūros grandies gydytoju. Dažnai gydytojas tampa pagrindiniu gyventojų motyvu pasirenkant patikras (14).

Apibendrinus ŠKL PP efektyvumo vertinimo tyrimus, pastebèta, kad šie tyrimai dažniausiai atliekami Valstybinès ligonių kasos užsakymu ir juos pavesta vykdyti UAB „Baltijos tyrimai“. Moksliniu požiūriu dažniausiai vertinamas gyventojų informuotumas, dalyvavimas ir požiūris i prevencines programas, atsižvelgiant $\mathfrak{i}$ demografinius ir socialinius veiksnius.

Apibendrinus pastebima, kad nors didžioji dalis gyventojų žino apie širdies ir kraujagyslių ligų ankstyvos diagnostikos programas ir teigia apie jų reikalingumą, tačiau dalyvavimas jose išlieka žemas. Didesnioji dalis respondentų norètų gauti daugiau informacijos apie ŠKL prevencinę programą.

\section{Išvados}

1. ŠKKL daugiausia įtakos turi nesveika mityba, nutukimas, sėslus gyvenimas, alkoholio vartojimas, rūkymas ir aukštas kraujospūdis. Taip pat aktualus rizikos veiksnys - tai veiksmingo ir koordinuoto reagavimo ị širdies ir kraujagyslių ligas stoka, kitaip tariant ugdymo šiais klausimais stoka. Ugdant gyventojus galima išvengti daugelio širdies ir kraujagyslių ligų bei pailginti žmonių gyvenimą. Vykdoma Lietuvoje širdies ir kraujagyslių ligų prevencinė programa sukurta siekiant sumažinti sergamumą širdies ir kraujagyslių ligomis.

2. Tyrimas atskleide, kad Klaipèdos miesto gyventojai turi žalingų ịpročių. Gyventojai atmestinai žiūri ị papildų, gerinančių jų širdies darbą, vartojimą. Moterys daug labiau domisi sveika gyvensena, nei vyrai. Vyrai yra linkę mankštintis daugiau, nei moterys. Saldumynais labiau linkę 
piktnaudžiauti taip pat vyrai.

3. Apibendrinus Klaipèdos miesto gyventojų žinias apie galimybę dalyvauti širdies ir kraujagyslių ligų prevencinejje programoje nustatyta, kad apie Lietuvoje vykdomą nemokamą širdies ir kraujagyslių ligų prevencijos programą žino apie 80 proc. apklaustujų. Tyrimo metu nustatyta, kad beveik visi apklaustieji respondentai sutinka, kad dalyvavimas ŠKL programoje gali sumažinti mirtingumą širdies ir kraujagyslių ligomis. Nors turi nemažai žinių, tačiau programoje dalyvavo tik puse apklaustųų .

4. Identifikuota, kad faktiškai 70 proc. Klaipedos miesto gyventojų turi pakankamai žinių kur kreiptis, norint sudalyvauti širdies ir kraujagyslių ligų prevencinèje programoje. Tik du trečdaliai respondentų tiksliai žino amžiaus grupes, kurioms skirta nemokama širdies ir kraujagyslių ligų prevencijos programa. Nustatyta, kad tik du trečdaliai žino, kad šia programa galima pasinaudoti tik kartą per metus. Pagrindinis informavimo šaltinis apie ŠKL prevencinę programą Klaipedos gyventojų nuomone - šeimos gydytojas arba slaugytojas. Galima konstatuoti, kad šios programos sklaida yra pakankamai vykdoma.

\section{Literatūra}

1. Baltijos tyrimai. Lietuvos gyventojų apklausa apie informuotumą ir pasitikejimą ligonių kasomis bei apie prevencines programas 2017. [žiūrèta 201904 22]. Prieiga per: http://www.vlk. 1t/naujienos/tyrimai/Documents/VLK-2017-10-prezentacija-27\%20d.pdf.

2. Boguševičiūtė A., Diržytė A., Boguševičius A. Moterų dalyvavimo atrankinès mamografinès patikros dèl krūties vėžio programoje motyvai. Medicina, 2003; 39(10): 1007-1015.

3. Brotons C, Lobos JM, Royo-Bordonada M, Maiques A, de Santiago A, Castellanos Á, Lizcano Á. Implementation of Spanish adaptation of the European Guidelines on cardiovascular disease prevention in primary care. BMC Family Practice $2013 ; 14,36$.

https://doi.org/10.1186/1471-2296-14-36

4. Cardiovascular diseases statistics. Eurostat Statistics Explained. 2018. [žiūrèta 201902 15]. Prieiga per: https://ec.europa.eu/ eurostat/statistics-explained/index.php/Cardiovascular_diseases_statistics\#Cardiovascular_healthcare;

5. Council of the European Union. Council Recommendation of 2 December 2003 on Cancer Screening. 2003, 878/EC.

6. Lagerlund M, Hedin A, Sparén P, Thurfjell E, Lambe M. Attitudes, beliefs, and knowledge as predictors of nonattendance in a Swedish population-based mammography screening program. Prev Med 2000; 31(4):417-28.

https://doi.org/10.1006/pmed.2000.0723

7. Lietuvos sveikatos statistika (Health Statistics of Lithuania). 2016. Higienos instituto Sveikatos informacijos centras 2017.

8. Line F, Jensen LF, Mukai TO, Andersen B, Vedsted P. The association between general practitioners' attitudes towards breast cancer screening and women's screening participation. BMC Cancer 2012.

https://doi.org/10.1186/1471-2407-12-254

9. Perk J, Backer G.D, Gohlke H, Graham I, Reiner Ž, Vershuren M. et al. European Guidelines on cardiovascular disease prevention in clinical practice (version 2012). European Heart Journal 2012; 33: 1635-1701.

https://doi.org/10.1093/eurheartj/ehs092

10. Lietuvos Respublikos sveikatos apsaugos ministro $2005 \mathrm{~m}$. lapkričio 25 d. įsakymas Nr. V-913 "Dèl Asmenų, priskirtinų širdies ir kraujagyslių ligų didelès rizikos grupei, atrankos ir prevencijos priemonių finansavimo programos patvirtinimo: Valstybės žinios, 2005; 145-5288.

11. Petronytė G., Kanapeckienė V., Eigirdaitė A., Jurkuvėnas A. Gyventojų informuotumą, dalyvavimą ir požiūrị ị onkologinių ir širdies kraujagyslių ligų prevencines programas sąlygojantys veiksniai. Visuomenès sveikata, 2013; 2 (61): 31-7.

12. Schueler KM, Chu PW, Smith-Bindman R. Factors associated with mammography utilization: a systematic quantitative review of the literature. J Womens Health 2008; 17(9): 1477-98. https://doi.org/10.1089/jwh.2007.0603

13. Svavarsdóttir M.H, Sigurðardóttir A.K, Steinsbekk A. Knowledge and skills needed for patient education for individuals with coronary heart disease: the perspective of health professionals. European Journal of Cardiovascular Nursing 2016; 15(1):55 -63.

https://doi.org/10.1177/1474515114551123

14. Verikienė J., Jankauskienė D. Projekto "Pacientų ir sveikatos priežiūros paslaugų teikèjų apklausos atlikimas ir analizès parengimas ataskaita, 2012; 9,32.

\section{RESIDENTS AWARENESS ABOUT THE CARDIOVASCULAR DISEASES PREVENTION PROGRAM \\ S.Norkiené, N.Pakalniškienė}

Key words: cardiovascular diseases, prevention program Summary

Circulatory system diseases are one of the leading causes of mortality in all EU Member Countries: they accounted for 50$60 \%$ of all deaths in the Baltic States and Romania. It is noticed that residents of Lithuania, irrespective of their age, social status and education, do not care enough about their health. This may depend on a number of reasons but one of the most important is the lack of knowledge about these diseases. Pre-diagnosis and treatment of relevant circulatory disorders, rehabilitation and preventive programs involving healthy lifestyle training can significantly reduce the spread of cardiovascular disease. In Lithuania primary health care institutions perform services of cardiovascular risk assessment, establishment of a primary prevention plan, and detailed analysis of the risk of cardiovascular diseases. In Lithuania participation in the preventive programs is increasing every year, but various surveys and researches show that the majority do not 
have enough information about the prevention programs in Lithuania therefore the maximum participation of the population in such programs is not achieve.

Methodology: 120 Klaipeda residents participated in the questionnaire, 60 men and 60 women. Statistical data analysis was performed using IBM SPSS 25.

Results. The main objective of this program to reduce cardiovascular morbidity knows majority of respondents (65 percent), but 23.6 percent do not know the goal. 7 out of 10 respondents about the prevention program were informed by the family doctor or nurse. All respondents agree that participation in cardiovascular disease program can reduce cardiovascular mortality. The knowledge of the preventive program is very similar for both men and women only the lifestyle differs. Only a healthy lifestyle, exercise habits, sweets consumption, and frequency of participation in the preventive program are statistically significantly different among men and women. It has been found that women are more interested in a healthy lifestyle than men. It is noted that although the majority of the population is aware of the early diagnosis programs for cardiovascular disease and claim their necessity, participation in them remains low. The majority of respondents would like to have more information prevention program.

Correspondence to: sigute.norkiene@gmail.com

Gauta 2019-05-16 